\title{
谈村镇建设中农村生活污水处理设施的选择
}

\author{
周雄坤 \\ 云南省曲靖市师宗县葵山镇国土和村镇规划建设服务中心 \\ DOI:10.32629/eep.v3i2.654
}

[摘 要] 从目前情况来说, 污水处理是制约村镇建设与发展的重要因素, 如果没有及时对污水进行全面处理, 必将会给群众生活及村镇生活环境 造成直接影响。但是, 受到地区经济因素等影响, 村镇生活污水处理设施建设比较落后, 因此怎样才能合理选择农村污水处理设施, 是现阶段农村 建设发展重点思考的问题。本文就结合农村生活污水来源, 重点对村镇建设中农村生活污水处理设备进行分析, 并结合农村生活污水处理情况, 提出相应的建议,具体内容如下。

[关键词] 村镇建设; 农村生活污水; 处理设施

随着时代的发展, 国家也越来越注重三农问题, 并且, 在怎样改善农村 群众生活环境上做出了诸多努力, 获取的效果也比较理想, 在给农村群众 提供良好的生活环境的同时, 也给农村群众创造了更多收益。但是农村和 城市环境相比较, 依然存在诸多问题。为了改善农村环境, 实现农村经济的 稳定发展, 做好农村生活污水处理工作是非常必要的。下面本文将重点对 农村建设中农村生活污水处理设施选择进行深入探讨。

\section{1 农村生活污水的来源}

农村生活污水也就是指在农村生活过程中, 人们常用于生活所需而产 生的污水。在我们实际生活中, 各个方面都需要水源的支持, 因此在生活中, 必将会产生大量的生活污水, 例如, 洗衣服、洗菜、洗碗等。针对这些生活 污水来说, 只有对其进行全面处理, 才能将其排放到河流中, 从而降低对周 围生态环境的影响 ${ }^{[1]}$ 。但是在部分农村中, 生活污水没有得到全面处理。其 中大部分农村群众在家中饲养牲畜, 部分农村群众依靠养殖来生活, 在此 过程中必然会产生大量的生活污水。由于农村群众环境保护意识比较薄弱, 没有在家庭中使用污水处理设备, 使得在畜牧养殖过程中将会产生大量废 水, 并直接排放到河流中, 给农村生活环境造成严重破坏。

\section{2 村镇建设中农村生活污水处理设备}

2. 1 化粪池

化粪池也就是利用沉淀的原理, 将农村生活污水中的悬浮物进行沉淀 处理。在化粪池中主要采取的处理工艺有两个, 一个是厌氧, 另一个是沉 降。通常情况下, 农村群众在建设化粪池时, 一般会采取三个化粪池, 其中 冲厕水由第一格进入分别流入到第二、第三格中, 并进行沉淀和庈氧处理。 而生活洗涤用水则直接进入到第三格中, 通过沉淀处理后再出水。农村生 活污水经过化粪池处理后, 能够将污水中的部分物质进行降解, 能够降低 对生态环境的影响。但是在使用该处污水处理设备过程中, 其去溶解性污 染物的效果不理想, 无法满足国家污水处理要求。即便当前已经对化粪池 进行了深入改良, 污水处理效果要比之前好, 但是依然不满足国家水质要 求, 因此在使用上存在局限性。

2. 2 厌氧污水处理设施

厌氧处理设备也就是, 通过使用厌氧微生物将有机物进行分解, 将其 转变为甲烷和二氧化碳, 是一个具有去除有机污染物的设备。在厌氧污水 处理设备中, 通过悬挂一个微生物附着生长填料, 从而提升有机污染物的 去除效率。但是在使用这种设备时, 由于其中涉及了厌氧环节, 不能有效保 证出水质量 ${ }^{[2]}$ 。这种设备通常是用于污水处理要求比较低的区域, 最好在 末端预留一定的空闲土地, 便于工艺改造。

2. 3 微动力污水处理设施

通常来说, 微动力污水处理设备, 也就是利用厌氧-好氧工艺将污水传
递到设备中, 设备内部设有生物填料, 能够增加微生物附着表面积, 通过厌 氧及好氧生物处理, 将有机物进行分解。在污水停留在设备内一段时间后, 微生物将会对有机物进行生物降解, 并去除一定的污染物。经过处理后的 污水, 部分可以排放到河流中, 另一部分则沉淀在污泥回流中。这种设备工 艺比较成熟, 处理效果比较好, 在农村生活污水处理中应用较为广泛。

2. 4 人工湿地

在人工湿地中, 融合了生物、化学、物理等科学。在对生活污水处理 过程中, 处理原则和沼泽基本相同, 通过人为建设, 加强监督管理, 利用沼 泽地进行生活污水处理。在湿地中, 通过种植水草等水生植物, 让土壤具有 渗滤功能, 并且在水生植物的作用下, 能够改善湿地内部污水情况, 实现生 态环境的治理。在湿地填料表面含有大量的微生物, 在微生物的作用下形 成生物膜, 有机污染物通过生物膜进行去除。并且水生植物根系, 能够及时 将污水中的氮、磷等物质进行吸收, 转变成营养物质。由于人工湿地主要 适合应用在经济条件不高且污水中氮磷去除要求低的区域, 通过其地势差 及当地闲置湿地等, 实现生活污水的处理。

\section{3 村镇建设中农村生活污水处理建议}

3. 1 完善污水收集体系

在村镇建设过程中, 为了实现农村生活污水的全面处理, 需要做好污 水收集工作, 这也是污水处理的重要内容, 便于后续生活污水处理工作顺 利进行。在污水收集过程中, 需要结合实际情况, 制定完善的污水收集体系, 提高污水收集效率。在进行农村污水收集管网建设时, 需要按照国家要求, 保障其正常运行。并且, 综合思考农村群众生活习惯和经济发展情况, 容易 出现管网堵塞、污水收集率偏低等问题。所以在农村污水处理过程中, 不可 按照城市污水处理方法进行。针对农村户内与户外生活污水收集, 经济发展 条件好的区域, 可以采取一体化净水槽技术, 通过多个分区收集污水 ${ }^{[3]}$ 。对 于经济发展比较落后的村镇, 则应该采取小型人工湿地系统。在污水系统 建设后期, 应该做好维护工作, 并与当地农村群众建立合作契约, 让农村群 众在日常生活中对污水管网进行保护和处理, 强化农村群众环境保护意识, 改变其生活习惯, 从根源上减少污水排放。

3.2 引进微动力污水处理设施

随着村镇建设水平的不断提高, 农村生活污水处理技术也得到了改革 优化, 而微动力污水处理设备能够更好满足当前农村生活污水处理要求。在 对农村生活污水进行处理过程中, 需要秉持因地制宜原则, 积极建设砖块 砌筑处理池。由于开污水处理设备出的效果比较理想, 工艺成熟, 其活性污 泥沉淀性能良好, 能够实现泥水充分分离, 不会发生污泥膨胀等现象, 能够 有效处理农村生活污水问题。

3. 3加强人工湿地处理 


\title{
大型水电工程建设征地移民安置专项验收问题
}

\author{
梁炳华 \\ 新疆额尔齐斯河流域开发工程建设管理局 \\ DOI:10.32629/eep.v3i2.669
}

[ 摘 要] 移民安置验收是水电工程验收的重要组成部分。大型水电工程覆盖范围广、搬迁移民多, 积极开展移民安置验收工作, 是维护移民群 体根本权益,增大移民群体生产力,促进区域经济可持续发展的关键举措,需要引起社会各界的高度关注。

[关键词] 大型水电工程; 移民安置; 专项验收

当前, 国内水电工程建设数量与规模不断扩张, 技术创新也取得了有目 共睹的成绩。本文论述了大型水电工程建设征地移民安置验收的核心内涵 与实际价值, 分析了验收环节存在的各类问题, 并提出了相应的改进策略。

\section{1 大型水电工程建设征地移民安置验收的核心内涵}

1. 1 验收类型

大型水电工程项目验收主要分为阶段性验收和总体竣工验收两类。同 样的, 大型水电工程建设征地移民安置验收也分为两类。基于大型水电工 程建设遵循 “先移民后建设” 的理念原则, 阶段性验收具体包括如下两方 面内容:

第一, 工程截流建设征地移民安置验收。按照大型水电工程建设覆盖 面的空间区域差异, 可以将工程截流建设征地移民安置验收划分为围堰淹 没区建设征地移民安置验收和枢纽工程建设区建设征地移民安置验收两 部分。第二, 工程蓄水建设征地移民安置验收。针对大型水电工程项目, 可以结合水库蓄水进度计划和建设征地移民安置计划进行分批次验收。由 此, 简化验收流程, 节省时间成本。

\section{2 验收内容}

大型水电工程建设征地移民安置验收是一项综合性较强的工作, 涉及 内容极其复杂。大型水电工程建设征地移民安置验收工作具体包括如下几 方面内容: 其一, 审核认定工程建设征地范围。按照大型水电工程建设覆 盖面空间区域差异, 可以将工程截流建设征地移民安置验收划分为围堰淹 没区建设征地移民安置验收和枢纽工程建设区建设征地移民安置验收两 部分。其中, 围堰淹没区主要包括长期处于蓄水位以下的部位、正常蓄水 位以上受风浪、航运与意外情况等影响的临时淹没部位。

其二, 以实物指标为主导。经实物调查后, 对未通过 $5 \mathrm{~A}$ 审核标准的项目

单一的人工湿地污水处理方法在部分区域污水处理过程中, 已经无法 满足污水处理多元化需求, 因此当前人工湿地应采取厌氧设备与好氧设备 充分结合的处理模式, 形成两级复合人工湿地。通过采取这种方式, 能够有 效处理农村污水问题, 更好满足当地区污水处理要求, 能够有效提高污水 处理水平, 保证出水质量。

\section{4加强运行维护管理}

为了将农村生活污水处理系统, 自身功能充分发挥, 除了要合理选择 污水处理设备之外, 还要对污水处理设备运行情况进行监管和维护。在农 村生活污水处理系统运行中, 需要定期对污水处理情况进行追踪和监管, 保证污水处理系统能够正常运行。如果污水排放管道出现渗漏或者堵塞现 象, 应该及时检修和维护 ${ }^{[4]}$ 。并且相关人员需要定期对排水管道进出水情 况进行检查, 当地政府部门需要总结其他区域生活污水处理经验, 加大资 金投放力度, 给治理农村生活污水提供支持。

\section{4 结束语}

实行重新调查。另外, 还包括农村移民安置规划执行情况; 城镇搬迁建设 规划执行情况; 特定项目搬迁复建规划执行情况; 建设征地移民安置补偿 体制执行情况; 建设征地移民安置补偿费用分配方案执行情况; 建设征地 移民安置档案管理情况; 建设征地移民安置践法履约情况; 建设征地移民 安置贫困户救助补偿机制执行情况; 建设征地移民安置监理落实情况。

1.3验收程序

在水电工程建设征地移民安置验收时, 首先, 由水电工程建设项目法 人向所在区域发改委与能源局呈递工程蓄水验收申请。其次, 在水电工程 主体部分交付竣工, 或发电机组设备投产使用后一年内, 开展竣工验收工 作, 既可以独项验收, 也可以与枢纽工程协同验收, 如期呈递水电工程项目 竣工验收申请。若水电工程项目经过核准, 基层政府部门要积极开展移民 验收工作。大型水电工程建设征地移民安置验收工作流程如下所述:

由国家发改委与能源局组织开展水电工程阶段性验收与竣工验收; 由 基层政府部门组织开展水电工程建设征地移民安置验收; 由基层发改委与 能源局提出水电工程建设阶段性验收或竣工验收初审意见。

\section{2 大型水电工程建设移民安置验收的实际价值}

首先, 大型水电工程属于国家级重点工程项目, 建设规模大、覆盖范围 广、搬迁移民多、投资成本高。同时, 经济效益与社会效益也相当显著。 为此, 工程建设完毕后必须经过鉴定与评价。移民安置验收是水电工程竣 工验收的重要组成部分, 这同时也是新时期背景下依法治国的必然要求。

其次, 积极开展水电工程建设征地移民安置验收, 有利于客观审核移 民安置工作是否符合国家法律法规及行业规章条例; 审核移民安置工作落 实效果是否达到长期规划发展目标; 审核移民群体社会产生力水平与生活 水平是否恢复到原有程度。

总而言之, 在村镇建设中, 农村生活污水处理作为重要内容, 直接影响 农村生活环境与品质, 不但给当地农村群众提供额外资源, 也能实现农村 建设的稳定发展。因此相关部门需要综合思考当地农村生活污水排放情况, 合理选择农村污水处理设施, 在经济能力范围内保证污水处理设备稳定运 行, 获取理想的处理效果, 给广大农村群众生活发展谋福利。

\section{[参考文献]}

[1]王靖宇.浅析广东省PPP模式推进农村生活污水处理设施建设的现 状和建议[J].广东化工,2019,46(01):118+124.

[2]于法稳, 于婷.农村生活污水治理模式及对策研究[J]. 重庆社会科 学,2019,(03):6-17+2.

[3] 于婷, 于法稳. 农村生活污水治理相关研究进展 [J]. 生态经 济,2019,35(07):209-213+220.

[4]姜珊,李想,姜彩红,等.农村生活污水处理的现状分析和对策建议 [J].安徽农学通报,2019,25(23):122-125. 